\title{
DAYA SAING USAHA TANI PADI DI KECAMATAN SUSUKAN KABUPATEN SEMARANG MENGGUNAKAN METODE PAM (POLICY ANALYSIS MATRIX)
}

\section{Competitive and Comparative Advantage of Rice Business in Susukan Subdistrict of Semarang Regency using PAM (Policy Analysis Matrix) Method}

\author{
Yoanes Krisostomos Nargy Justra Septarisco ${ }^{1)}$, Tinjung Mary Prihtanti ${ }^{2)^{*}}$ \\ 1) Mahasiswa Program Studi Agribisnis Universitas Kristen Satya Wacana \\ ${ }^{2)}$ Staf pengajar Program Studi Agribisnis Universitas Kristen Satya Wacana \\ Corresponding author*tinjung.murjono@gmail.com
}

\begin{abstract}
Competitiveness requires a country to excel in competitive and comparative advantage. The commodities that need to be developed are rice. This commodity was chosen because it is a commodity that the government prioritizes and is full of agricultural policies. The purpose of this study is to determine profits, competitive and comparative advantages and the impact of government policies. This research was conducted in March 2018 in Susukan District, Semarang Regency. The sampling technique used purposive sampling technique with a total of 30 respondents. Data analysis using Policy Analysis Matrix (PAM). The results showed that farming has a competitive and comparative advantage seen from the value of PCR and DRCR less than 1 but the DRCR value of 0.935 means that farming is feared no longer has comparative advantage if there is no interference from government policy. For the government, the policy of subsidizing fertilizers and pesticides is continued so that the farming business remains competitive but the use of fertilizer by farmers should be reduced so that it is in accordance with recommendations from the Agriculture Service or researchers. Marketers should target the domestic market because the price of rice in the international market is lower than in the country..
\end{abstract}

Keywords: Rice Farming, Competitiveness, PAM, Susukan

\begin{abstract}
ABSTRAK
Daya saing dibutuhkan suatu negara untuk unggul secara kompetitif dan komparatif. Komoditas yang perlu dikembangkan adalah padi. Komoditas ini dipilih karena merupakan komoditas yang diprioritaskan pemerintah dan sarat akan kebijakan pertanian. Tujuan penelitian ini adalah untuk menentukan keuntungan, keunggulan kompetitif dan komparatif serta dampak kebijakan pemerintah. Penelitian ini dilakukan pada bulan Maret 2018 di Kecamatan Susukan, Kabupaten Semarang. Teknik pengambilan sampel menggunakan teknik purposive sampling dengan total 30 responden. Analisis data menggunakan Policy Analysis Matrix (PAM). Hasil penelitian menunjukkan bahwa usahatani memiliki keunggulan kompetitif dan komparatif dilihat dari nilai PCR dan DRCR kurang dari 1 namun nilai DRCR sebesar 0,935 berarti bahwa usaha tani dikhawatirkan tidak lagi memiliki keunggulan komparatif jika tidak ada interfensi dari kebijakan pemerintah. Untuk pemerintah, kebijakan pemberian subsidi pupuk dan pestisida tetap dilanjutkan agar usaha tani tetap kompetitif namun penggunaan pupuk oleh petani sebaiknya dikurangi sehingga sesuai dengan rekomendasi dari Dinas Pertanian atau peneliti. Untuk pemasar sebaiknya menargetkan pasar domestik karena harga beras di pasar internasional lebih rendah dari pada dalam negeri.

Kata kunci : Usaha Tani Padi, Daya Saing, PAM, Susukan
\end{abstract}




\section{PENDAHULUAN}

Perdagangan bebas sudah dimulai dan Indonesia dituntut untuk mampu bersaing di dalam dan luar negeri khususnya untuk komoditas pertanian. Salah satu komoditas yang banyak dibudidayakan dan menjadi salah satu komoditas pangan prioritas yaitu padi. Padi (beras) menjadi prioritas karena besarnya tingkat konsumsi beras dalam negeri yang mencapai 132,98 kg/kapita/tahun. Semakin bertambahnya penduduk, konsumsi juga semakin meningkat sehingga padi diprioritaskan untuk mengatasi kekurangan suplai di dalam negeri.Dibutuhkan adanya analisis daya saing untuk menilai apakah usaha tani akan tetap eksis dan memiliki daya saing. Ketika komoditas padi memiliki daya saing maka akan diikuti dengan peningkatan produksi dalam negeri, pendapatan petani dan penambahan devisa dari perdagangan internasional (Dewi, et al., 2013)

Teknik budidaya padi di Indonesia rata-rata mengunakan cara konvensional atau anorganik (Ali, Purwanti, \& Hidayati, 2019). Padi anorganik banyak dibudidayakan karena memiliki produktifitas lebih tinggi. Namun, tingginya produksi diikuti juga dengan penggunaan input yang besar yaitu pupuk dan pestisida. Input padi kebanyakan menggunakan input tradable atau input yang diperdagangkan secara internasional. Kenaikan harga input dunia akan membuat input dalam negeri juga meningkat sehingga dibutuhkan peran pemerintah untuk membantu petani agar usaha tani tetap efisien dan menguntungkan.

Beras merupakan komoditas yang sarat dengan kebijakan pemerintah. Pemerintah menetapkan beberapa kebijakan terkait komoditas beras maupun usahatani padi, anatara lain Penetapan harga eceran tertinggi untuk beras dan pupuk bersubsidi. Penetapan harga eceran tertinggi beras tercantum pada Peraturan
Menteri Perdagangan Republik Indonesia NO 57/M-dag/PER/8/2017. Dengan adanya peraturan tersebut harga beras dibatasi untuk beras medium Rp 9.450 dan untuk beras premium Rp 12.800. Peraturan mengenai harga eceran pupuk bersubsidi tercantum dalam Peraturan Menteri Pertanian Nomor 47/Permentan/SR.310/12/2017 yang menjabarkan HET pupuk urea Rp 1800/kg, pupuk SP-36 Rp 2.000/kg, pupuk Za Rp $1.400 / \mathrm{kg}$, pupuk NPK Rp $2.300 / \mathrm{kg}$ dan Pupuk organik Rp 500/ha. Peraturan peraturan tersebut akan menambah efisiensi dan daya saing usahatani padi khususnya dalam hal pemenuhan input dan output produksi.

Pendekatan yang sering digunakan untuk megukur daya saing yaitu keunggulan komparatif dan keunggulan kompetitif. Keunggulan komparatif bermanfaat dalam kaitannya dengan perdagangan internasonal. Apabila negara mengkonsentrasikan diri untuk mengekspor barang yang bagi negara tersebut memiliki keunggulan yang komparatif, negara tersebut akan beruntung karena berarti produksinya lebih efisien dan mampu bersaing. Maka dari itu, seorang perencana wilayah harus memiliki kemampuan untuk menganalisa potensi ekonomi wilayahnya (Tarigan, 2005). Keunggulan kompetitif (competitive advantage) dibutuhkan agar produsen dalam hal ini petani mampu bersaing dengan produsen lain didalam negeri dengan produk yang sama. Pengukuraan keunggulan kompetitif dan komparatif dapat dilakukan dengan menghitung keuntungan privat dan sosial menggunakan analisis PAM (Monke \& Pearson, 1989).

Beberapa penelitian sebelumnya yang menggunakan metode PAM yaitu komoditas kentang, jeruk siam, beras organik, biji pala dan kelapa. Hasil penelitian untuk komoditas kentang di Kota Batu yaitu kentang memiliki keunggulan kompetitif dan komparatif pada sistem intensif maupun konvensional 
JURNAL ILMIAH AGRINECA

ISSN : 2721-074X (Online) - 2301-6698 (Print)

Available on : http://ejournal.utp.ac.id/index.php/AFP/index

This is Under CC BY SA Licence

dengan nilai DRCR < 1 (Dewi, et al., 2013).Jeruk Siam Jember juga memiliki keunggulan komparatif dan kompetitif meskipun dari segi input petani harus membayar harga yang lebih mahal dan menerima harga output yang lebih murah dibandingkan jika tidak ada kebijakan dan distorsi pasar sehingga perlu upaya untuk meningkatkan daya saing jeruk Siam(Sayekti \& Zamzami, 2011).Usaha tani beras organik di Kabupaten Tasikmalaya memiliki keunggulan kompetitif dan komparatif dan dampak negatif hanya terjadi pada penyediaan input seperti pupuk dan benih organik(Jakiyah, et al., 2016).Usaha tani biji pala menguntungkan secara privat maupun sosial(Gerungan, 2013).Usaha tani kelapa di Kabupaten Kupang tidak memiliki keunggulan kompetitif karena nilai PCR >1 namun memiliki keunggulan komparatif karena nilai DRCR $<1$ (Setiawan, et al., 2014).

Kecamatan Susukan merupakan salah satu daerah potensial penghasil padi di Kabupaten Semarang. Dari berbagai komoditas tanaman pangan, padi merupakan komoditas terbesar yang dihasilkan di Kecamatan ini. Pada tahun 2016 produksi padi di kecamatan ini mencapai 27.371,34 ton. Dengan demikian dirumuskan tujuan penelitian yaitu (1) mengetahui keuntungan usaha tani padi; (2) mengetahui keunggulan kompetitif dan komparatif usaha tani padi;(3) mengetahui dampak kebijakan terhadap usaha tani padi.Manfaat penelitian ini yaitu diharapkandapat menambah khasanah ilmu pengetahuan di bidang sosial ekonomi pertanian, khususnya mengenai kebijakankebijakan pertanian untuk komoditas padi. Hasil penelitian ini juga dapat menjadi bahan pertimbangan dan informasi bagi pemerintah untuk mengevaluasi kebijakan-kebijakan yang sudah dijalankan.

\section{METODE PENELITIAN}

Penelitian dilakukan di Kecamatan Susukan Kabupaten Semarang khususnya diDesa Badran, Gentan, Kemetul, Kenteng, Ketapang, Koripan, Muncar, Sidoharjo, Susukan, dan Timpik. Pemilihan lokasi berdasarkan potensi desa dalam menghasilkan padi. Kecamatan Susukan memiliki luas $4.886,48 \mathrm{Ha}$ atau $5,14 \%$ dari luas Kabupaten Semarang. Penggunaan lahan di kecamatan ini terbagi menjadi dua yaitu sebagai lahan pertanian seluas 3.610,3 Ha dan lahan bukan pertanian seluas 1.276,18 Ha. Secara administratif Kecamatan Susukan di batasi oleh Kecamatan Tengaran, Kabupaten Boyolali, Kecamatan Suruh dan Kecamatan Kaliwungu. Ketinggian ratarata yaitu 495 meter diatas permukaan laut. Ketinggian tersebut sesuai untuk budidaya pertanian khususnya tanaman padi karena padi mampu tumbuh pada ketinggian 0 sampai 1500 meter diatas permukaan laut. Waktu penelitian yaitu bulan Maret tahun 2018.

Penelitian ini merupakan jenis penelitian deskriptif kuantitatif. Penelitian deskriptif adalah penelitian yang mendeskripsikan hal-hal yang saat ini berlaku. Penelitian ini tidak menguji hipotesis melainkan hanya mendeskripsikan informasi apa adanya sesuai dengan variabel yang diteliti. Penelitian deskriptif dimaksudkan untuk menggambarkansecara sistematis dan cermat fakta-fakta aktual dan sifat populasi tertentu (Darmawan, 2014).

Pengambilan sampel dilakukan secara nonprobability sampling dengan teknik purposive sampling. Purposive sampling adalah teknik untuk menentukan sampel penelitian dengan beberapa pertimbangan tertentu yang bertujuan agar data yang diperoleh nantinya bisa lebih representatif (Sugiyono, 2010). Kriteria yang dibutuhkan yaitu petani mampu melakukan perhitungan input dan output produksi, status responden merupakan 
JURNAL ILMIAH AGRINECA

ISSN : 2721-074X (Online) - 2301-6698 (Print)

Available on : http://ejournal.utp.ac.id/index.php/AFP/index

This is Under CC BY SA Licence

pemilik lahan atau penyewa dan jenis padi tidak dibatasi varietas tanaman. Varietas tidak dibatasi tetapi beras yang dihasilkan adalah beras putih pecah kulit (PK) dengan faktor konversi gabah kering panen (GKP) menjadi gabah kering giling (GKG) sebesar $85 \%$ dan konversi gabah kering giling (GKG) menjadi beras 65\% (Anapu, H., et al, 2005).Sampel yang diabil yaitu sebanyak 30 responden.

Data yang diambil dibedakan menjadi data primer dan data sekunder. Data primer diperoleh dari sampel petani. Data sekunder diperoleh dari lembagalembaga terkait yaitu Dinas Pertanian dan BPS Kabupaten Semarang. Selain itu data sekunder juga didapat dari statistik internasional dan literatur ilmiah. Data primer diperoleh dengan teknik wawancara terstruktur sedangkan untuk data sekunder dengan menggunakan metode dokumenter.

Analisisdata menggunakan Policy Analysis Matrix (PAM)single periodkarena padi merupakan tanaman semusim. Pada tabel PAM harga dibedakan menjadi harga privat dan harga sosial. Harga privat diperoleh langsung dari hasil wawancara sedangkan harga sosial didapat dari harga internasional atau harga perbatasan (border price). Border priceyang digunakan yaitu harga CIF untuk barang yang diimpor dan FOB untuk barang yang diekspor atau potensian untuk diekspor.Sebelum digunakan sebagai perhiitungan, harga internasional tersebut dikonfersikan terlebih dahulu sehingga menjadi harga paritas ditingkat petani. Kontruksi Policy Analysis Matrix (PAM) disajikan pada tabel 1.

Tabel 1. Konstruksi Policy Analysis Matrix (PAM)

\begin{tabular}{lllll}
\hline \multirow{2}{*}{ Komponen } & Penerimaan & Biaya & & \\
\cline { 3 - 4 } & & InputTradable & $\begin{array}{l}\text { Input Non } \\
\text { Tradable }\end{array}$ & Keuntungan \\
\hline Harga Privat & $\mathrm{A}$ & $\mathrm{B}$ & $\mathrm{C}$ & $\mathrm{D}$ \\
Harga Sosial & $\mathrm{E}$ & $\mathrm{F}$ & $\mathrm{G}$ & $\mathrm{H}$ \\
Divergensi & $\mathrm{I}$ & $\mathrm{J}$ & $\mathrm{K}$ & $\mathrm{L}$ \\
\hline
\end{tabular}

Keterangan:

Daya Saing :

1. Keuntungan Privat $(\mathrm{D}=\mathrm{A}-\mathrm{B}-\mathrm{C})$

2. Keuntungan Sosial $(H=E-F-G)$

3. Keunggulan Komparatif $(\mathrm{DRCR}=\mathrm{G} /(\mathrm{E}-\mathrm{F}))$

4. Keunggulan Kompetitif $(\mathrm{PCR}=\mathrm{C} /(\mathrm{A}-\mathrm{B}))$

Kebijakan Input :

1. Transfer Input $(\mathrm{J}=\mathrm{B}-\mathrm{F})$

2. Transfer Faktor $(\mathrm{K}=\mathrm{C}-\mathrm{G})$

3. Koefisien Proteksi Nominal Input $(\mathrm{NPCI}=\mathrm{B} / \mathrm{F})$

Kebijakan Output :

1. Transfer Output $(I=A-E)$

2. Koefisien Proteksi Nominal Output $(\mathrm{NPCO}=\mathrm{A} / \mathrm{E})$

Kebijakan Input-Output :

1. Transfer Bersih $(\mathrm{L}=\mathrm{D}-\mathrm{H})$

2. Koefisien Keuntungan $(\mathrm{PC}=\mathrm{D} / \mathrm{H})$

3. Koefisien Proteksi Efektif $(\mathrm{EPC}=\mathrm{A}-\mathrm{B} / \mathrm{E}-\mathrm{F})$

4. Rasio Subsidi Produsen $(\mathrm{SRP}=\mathrm{L} / \mathrm{E})$

(Monke \& Pearson, 1989)

HASIL DAN PEMBAHASAN

Gambaran Umum Responden 
JURNAL ILMIAH AGRINECA

ISSN : 2721-074X (Online) - 2301-6698 (Print)

Available on : http://ejournal.utp.ac.id/index.php/AFP/index

This is Under CC BY SA Licence

Karakteristik responden dibedakan berdasarkan umur, tingkat pendidikan, lama bertani, luas lahan dan sistem irigasi. Berdasarkan umur, rata-rata responden berada pada interval umur 46 sampai 55 tahun.Berdasarkan tingkat pendidikan rata-rata responden pendidikan terakhir pada tingkat SD.Berdasarkan lama bertani,responden yang diteliti berada pada interval 16 sampai 25 tahun. Berdasarkan luas lahan, responden memiliki kepemilikan lahan padi dengan rerata seluas $5.482 \mathrm{~m}^{2}$. Berdasarkan keadaan irigasi, lahan milik responden usaha tani padi masih ada yang belum mendapatkan kemudahan air lewat saluran irigasi sebesar $10 \%$ dari total responden. Secara keseluruhan berdasarkan karakteristik responden tersebut mencerminkan kualitas sumber daya manusia untuk pertanian masih rendah terlihat dari umur yang sudah tua, pendidikan yang rendah, dan kepemilikan lahan yang masih kecil.

\section{Biaya Usaha Tani Padi}

Biaya input dalam penelitian ini secara garis besar dibedakan kedalam dua jenis yaitu input tradable dan input non tradable. Sedangkan untuk output merupakan hasil panen dari budidaya padi. Secara rinci kebutuhan dan biaya usaha tani padi disajikan pada Tabel 2

Tabel 2. Kebutuhan dan Harga Privat Usaha Tani Padi

\begin{tabular}{|c|c|c|c|c|}
\hline Input/Output & Jenis Input & satuan & $\begin{array}{l}\text { Jumlah } \\
\text { (satuan) }\end{array}$ & $\begin{array}{l}\text { Harga } \\
\text { (Rupiah) }\end{array}$ \\
\hline \multirow[t]{10}{*}{ Input Tradable } & Benih & $(\mathrm{Kg} / \mathrm{Ha})$ & 31,67 & 10.347 \\
\hline & Bahan Bakar transportasi & (liter/ha) & 3,40 & 6.550 \\
\hline & Bahan Bakar Traktor & (liter/ha) & 19,54 & 6.000 \\
\hline & Urea & $(\mathrm{Kg} / \mathrm{Ha})$ & 418,58 & 2.071 \\
\hline & Sp-36 & $(\mathrm{Kg} / \mathrm{Ha})$ & 108,49 & 2.292 \\
\hline & $\mathrm{KCL}$ & $(\mathrm{Kg} / \mathrm{Ha})$ & 52,78 & 3.375 \\
\hline & Phonska & $(\mathrm{Kg} / \mathrm{Ha})$ & 236,67 & 2.400 \\
\hline & Petroganik & $(\mathrm{Kg} / \mathrm{Ha})$ & 289,60 & 1.077 \\
\hline & Pestisida Padat & $(\mathrm{Kg} / \mathrm{Ha})$ & 1,60 & 168.096 \\
\hline & Pestisida Cair & (liter/ha) & 1,66 & 235.972 \\
\hline \multirow[t]{14}{*}{$\begin{array}{l}\text { Input Non } \\
\text { Tradable }\end{array}$} & Sewa Traktor & (hari) & 1,73 & 235.000 \\
\hline & Sewa lahan & (musim) & 1,00 & 2.500 .000 \\
\hline & Sewa threser & (hari) & 1,00 & 9.000 \\
\hline & Pupuk Cair & (liter/ha) & 4,47 & 26.400 \\
\hline & Alat Pertanian & (musim) & 1,00 & 206.000 \\
\hline & PBB & (musim) & 1,00 & 97.313 \\
\hline & Iuran Air & (musim) & 1,00 & 3.333 \\
\hline & Gabah Kering Giling & (Kg/ha) & $4.970,77$ & 209 \\
\hline & Pengolahan Lahan & (HOK/ha) & 36,12 & 40.172 \\
\hline & Tanam & (HOK/ha) & 28,07 & 39.167 \\
\hline & Penyiangan dan penyulaman & (HOK/ha) & 17,97 & 38.333 \\
\hline & Pemupukan & (HOK/ha) & 9,36 & 36.667 \\
\hline & Pengendalian hama & (HOK/ha) & 9,32 & 36.833 \\
\hline & Panen & (HOK/ha) & 17,32 & 98.333 \\
\hline
\end{tabular}


JURNAL ILMIAH AGRINECA

ISSN : 2721-074X (Online) - 2301-6698 (Print)

Available on : http://ejournal.utp.ac.id/index.php/AFP/index

This is Under CC BY SA Licence

\begin{tabular}{lllll}
\hline & Pengeringan/ Penjemuran & $(\mathrm{HOK} / \mathrm{ha})$ & 16,61 & 85.833 \\
& Modal Kerja & $(\%)$ & 6 & 14.736 .786 \\
Output & Beras & $(\mathrm{Kg} / \mathrm{ha})$ & $3.294,78$ & 9.115 \\
\hline
\end{tabular}

Sumber : Data primer diolah, 2018

Berdasarkan data diatas terdapat perbedaan penggunaan input.

\section{Benih}

Benih padi yang ditanam responden memiliki varietas dan penggunaan benih yang berbeda-beda. Varietas yang paling banyak ditanam yaitu IR64 dengan ratarata kebutuhan benih sebesar 31,67 kg/Ha. Banyak sedikitnya kebutuhan benih dipengaruhi beberapa faktor yaitu diantaranya luas lahan, keadaan cuaca pada saat penebaran benih, dan jarak tanam. Luas lahan berpengaruh karena lahanlahan yang sempit cenderung menggunakan benih lebih banyak karena ingin memaksimalkan keuntungan lewat jumlah benih yang ditanam. Keadaan cuaca berpengaruh karena ketika musim hujan benih- benih yang sudah ditaburkan bisa terpental akibat air hujan sehingga menjadi berkurang. Jarak tanam juga mempengaruhi kuantitas benih karena dengan semakin lebar jarak tanam benih yang dibutuhkan juga semakin sedikit. Pada lokasi penelitian jarak tanam yang digunakan bervariasi ada yang menerapkan sistem lama dan ada yang menggunakan jajar legowo.

Harga benih bervariasi sesuai varietas yang digunakan namun rata- rata harga benih yaitu Rp 10.347. Harga benih lebih tinggi disebabkan oleh varietasvarietas tertentu yang harganya lebih mahal. Walaupun demikian dilapangan terdapat beberapa responden usaha tani padi yang mendapatkan bantuan subsidi benih sehingga mengurangi biaya input untuk benih.

\section{Bahan Bakar}

Rata-rata penggunaan bahan bakar transportasi dan traktor pada usaha tani organik yaitu 3,40 liter/Ha dan 19,54 liter/Ha dalam satu musim. Kecilnya biaya transportasi disebabkan karena kebanyakan lokasi lahan responden tidak jauh dari rumah sehingga dapat dijangkau dengan jalan kaki. Harga privat dari bahan bakar transportasi yaitu Rp. 6.550 karena menggunakan bahan bakar bensin dan bahan bakar traktor Rp. 6.000 karena menggunakan bahan bakar solar.

\section{Pupuk}

Penggunaan pupuk Urea pada lokasi penelitian sebesar 418,58 kg/ha. Nilai tersebut terlalu tinggi jika dibandingkan dengan rekomendasi pemupukan yang seharusnya yaitu sebesar $200 \mathrm{~kg} / \mathrm{ha}$ sampai $290 \mathrm{~kg} / \mathrm{ha}$.Harga privat pupuk untuk yaitu Urea Rp 2.071,67/kg, SP-36 Rp $2.291,67 / \mathrm{kg} \quad \mathrm{KCL} \quad \mathrm{Rp} 3.375 / \mathrm{kg}$, NPK Phonska Rp 2.400/kg, Petroganik Rp $1.076,67 / \mathrm{kg}$ dan pupuk cair Rp 26.400 . Harga pupuk tersebut merupakan harga subsidi pemerintah. Namun ketidaksempurnaan dalam proses distribusi yang menjadi penghalang sehingga subsidi tidak merata itu terbukti dari lebih tingginya harga pupuk dibandingkan harga eceran tertinggi yang ditetapkan pemerintah.

\section{Pestisida}

Pestisida yang digunakan bermacam-macam sehingga dibedakan kedalam dua bentuk yaitu pestisida padat dan pestisida cair. Berdasarkan tabulasi data, kebutuhan pestisida cair yaitu sebesar 1,7 liter/Ha dengan harga privat sebesar Rp. 235.972,22/liter. Selain pestisida cair dibutuhkan juga pestisida padat. Kebutuhan pestisida padat pada lokasi penelitian yaitu $1,60 \mathrm{~kg} / \mathrm{Ha}$ dengan harga privat sebesar Rp. 168.096,15 /kg. Pestisida cair yang digunakan biasanya digunakan petani untuk mengatasi hama 
wereng, sundep, walang sangit dan serangga - serangga lainnya. Sedangkan, untuk pestisida padat biasanya digunakan untuk menangani hama tikus, wereng, dan bisa juga untuk memberantas rumput liar atau sebagai herbisida.

\section{Alat Pertanian}

Identifikasi kebutuhan alat pertanian dalam penelitian ini didasari oleh asumsi bahwa semua responden menganggarkan kebutuhan alat pertanian pada usaha taninya. Untuk mengetahui kebutuhan per musim alat pertanian diidentifikasi umur ekonomisnya. Umur ekonomis cangkul yaitu sepuluh tahun, ember dua tahun, dan tangki semprot tiga tahun. Harga privat dari ketiga alat pertanian tersebut yaitu cangkul Rp 165.000, ember Rp. 15.000 dan tangki semprot Rp. 600.000. Harga tersebut dikalikan dengan kuantitas alat yang digunakan petani dalam satu hektar.

\section{Sewa}

Sewa pada penelitian ini terdiri dari sewa traktor, threser dan sewa lahan. Sewa traktor pada usaha tani padi selama 1,73 hari. Lama tidaknya proses traktor disebabkan oleh kontur lahan dan letak lahan yang berbeda - beda. Kontur lahan yaitu memungkinkan atau tidaknya traktor masuk ke lahan mengingat keadaan geografis Kecamatan Susukan yang berbukit. Letak lahan petani juga tidak hanya satu tempat, bisa di dua sampai tiga tempat yang berbeda sehingga memakan waktu lama dalam penraktoran. Biaya privat sewa traktor untuk usaha tani padi sebesar Rp.235.000/hari.

Sewa selanjutnya yaitu biaya sewa threser. Baya sewa threser usaha tani selama satu hari dengan biaya privat Rp. 9.000,00. Biaya sewa theser kecil disebabkan beberapa responden tidak menggunakan threser tetapi panen dilakukan secara manual.

Sewa selanjutnya yaitu biaya sewa lahan. Biaya sewa lahan per hektar yaitu Rp. 1000/meter persegi atau Rp 10.000.000/tahun. Apabila dikonversi kedalam satu musim maka biaya sewa lahan sebesar Rp.2.500.000/musim.

\section{Pajak Bumi dan Bangunan}

Pajak yang dimasukkan dalam perhitungan yaitu pajak bumi dan bangunan dan berfokus pada pajak untuk lahan pertanian. Berdasarkan tabulasi data didapatkan bahwa pada satu musim, pajak usaha tani padi sebesar Rp 97.313,06/ha. Besaran pajak lahan petani berbeda-beda disebabkan oleh lokasinya. Lahan- lahan yang berada pada lokasi strategis, akses mudah maka nilai pajak juga semakin besar.

\section{Tenaga kerja}

Perhitungan tenaga kerja dibagi kedalam tujuh proses yaitu pengolahan lahan, tanam/tandur, penyiangan atau penyulaman, pemupukan, pengendalian hama, panen dan pengeringan. Dalam menghitung intensitas bekerja petani digunakan rumus hari orang kerja (HOK) dalam perhitungannya. HOK tersebut kemudian dikalikan dengan upah sehingga diketahui tingkat upah privat tenaga kerja. Nilai HOK yang rendah yaitu pada proses pemupukan dan pengendalian hama. Proses tersebut merupakan proses yang tidak memerlukan banyak tenaga dan kebanyakan dilakukan oleh tenaga kerja dalam keluarga sehingga nilai HOK rendah.

\section{Biaya Lain - lain}

Biaya lain-lain pada penelitian ini yaitu iuran air dan biaya giling. Iuran air merupakan biaya untuk petugas irigasi yang telah mengatur ketersediaan air pada lahan pertanian. Pada usaha tani padi memberikan kontribusi sebesar iuran irigasi sebesar Rp. 3.333,33. Kecilnya biaya iuran air ini disebabkan karena kebanyakan responden tidak memberikan ataupun tidak diminta untuk memberikan iuran bagi petugas irigasi dalam bentuk uang ataupun gabah ketika panen. 
ISSN : 2721-074X (Online) - 2301-6698 (Print)

Available on : http://ejournal.utp.ac.id/index.php/AFP/index

This is Under CC BY SA Licence

Biaya selanjutnya yaitu biaya giling. Biaya giling merupakan biaya yang dikeluarkan petani untuk menyelepkan/menggiling gabah kering giling (GKG). Berdasarkan tabulasi data gabah kering giling yang dihasilkan dengan mengalikan GKP dengan faktor konversi atau susut menjadi 85\% didapatkan kuantitas GKG usaha tani padi sebesar 4.970,77 kg/Ha. Harga privat untuk penggilingan yaitu Rp. 209. Besar kecilnya biaya giling ditentukan oleh masing-masing tempat penggilingan padi.

\section{Modal Kerja}

Modal dalam penelitian ini yaitu modal modal kerja (working capital). Menurut (Pearson, et al., 2005), modal kerja merupakan biaya produksi (tunai) yang harus dibayarkan petani untuk kebutuhan usaha taninya dalam satu tahun. Tingkat suku bunga modal diperlukan untuk mengetahui biaya tersebut. Berdasarkan pengamatan, seluruh modal untuk usaha tani yaitu dari modal pribadi. Namun berdasarkan penelitian- penelitian terdahulu modal kerja dapat diestimasi dengan tingkat suku bunga deposito Bank BRI di lokasi penelitian. Diketahui tingkat suku bunga deposito sebesar 6\% per tiga bulan (satu musim).

\section{Output}

Output yang diperoleh petani yaitu dari bobot beras dikalikan harga jual. Rata-rata hasil panen dalam bentuk beras untuk usaha taani sebesar 3.294,78 kg/ha. Rata-rata harga jual padi Rp. 9.115. Harga tersebut lebih rendah dari peraturan pemerintah mengenai HET tercantum pada Peraturan Menteri Perdagangan Republik Indonesia NO 57/M-dag/PER/8/2017. Dengan adanya peraturan tersebut harga beras dibatasi untuk beras medium $\mathrm{Rp}$ 9.450 dan untuk beras premium Rp 12.800.

\section{Harga Bayangan Usaha Tani Padi Organik dan}

Penetapan harga bayangan atau harga soial didasari oleh perhitungan harga internasional dengan mengkalkulasikan dengan penyesuaian -penyesuaian akibat dari kebijakan pemerintah. Kebijakan pemerintah yang mempengaruhi yaitu dari subsidi, pajak, tarif kebijakan harga. Selain itu distorsi pasar juga menyebabkan penyesuaian harga tersebut. Harga bayangan nilai tukar uang adalah harga uang domestik dalam kaitannya dengan mata uang asing. Perhitungan harga bayangan nilai tukar sebagai berikut:

Tabel 3. Perhitungan Harga Bayangan Nilai Tukar

\begin{tabular}{lr}
\hline Uraian & Nilai \\
\hline Nilai Ekspor (Juta Rupiah) & 2.059 .807 .328 \\
Nilai Impor (Juta Rupiah) & 1.898 .964 .850 \\
Pajak Ekspor (Juta Rupiah) & 340.100 \\
Pajak Impor (Juta Rupiah) & 33.735 .000 \\
SCF & 0,991 \\
OER & 13.384 \\
SER & 13.499 \\
\hline
\end{tabular}

Data Sekunder diolah (Badan Pusat Statistik, 2017)

Perhitungan Harga Bayangan Output

Harga bayangan beras diambil dari statistik Food and Agriculture Organization (FAO) dan dikonversi menjadi harga paritas di tingkat petani menjadi Rp 5.197/kg.

\section{Perhitungan Harga Bayangan Input}

1. Harga bayangan Benih Padi

\begin{tabular}{lrr}
\multicolumn{3}{r}{ Harga bayangan benih merupakan } \\
harga privatnya namun & dengan \\
menghilangkan faktor subsidi. & Setelah \\
menghilangkan faktor subsidi & maka
\end{tabular}


didapatkan harga sosial benih padisebesar Rp 11.546,67.

\section{Harga Bayangan Pupuk}

Pendugaan harga bayangan pupuk menggunakan harga internasional. Diketahui harga bayangan pupuk Urea Rp 3.527/kg, pupuk NPK Phonska Rp 5.023/ kg, pupuk KCL Rp 3.500/kg, dan pupuk SP-36 Rp 4.156.

\section{Harga Bayangan Pestisida}

Harga bayangan pestisida didapat dari harga privat dengan menghilangkan faktor subsidi. Subsidi pemerintah pada usaha tani terdapat pada subsidi pestisida padat khususnya untuk racun tikus. Setelah menghilangkan faktor subsidi tersebut maka didapatkan harga privat pestisida padat yaitu Rp. 257.519,23/kg. Tidak ditemukan adanya subsidi pada pestisida cair sehingga harga sosial pestisida cair sama dengan harga privatnya.

\section{Policy Analysis Matrix (PAM)}

Policy Analysis Matrix merupakan matrik untuk melihat apakah usaha tani menguntungkan secara privat maupun sosial. Hasil input data PAM tersaji pada tabel 4.

Tabel 4. Policy Analysis Matrix Usaha Tani Padi Organik

\begin{tabular}{ccccc}
\hline \multirow{2}{*}{ Komponen } & Penerimaan & \multicolumn{2}{l}{ Biaya } & \multicolumn{2}{l}{ Keuntungan } \\
\cline { 3 - 4 } & Input Tradable & $\begin{array}{l}\text { Input Non } \\
\text { Tradable }\end{array}$ & \\
\hline Harga Privat & 30.031 .956 & 3.301 .539 & 11.435 .247 & 15.295 .170 \\
\hline Harga Sosial & 16.790 .451 & 4.560 .166 & 11.435 .247 & 795.039 \\
\hline Divergensi & 13.241 .505 & -1.258 .627 & 0 & 14.500 .132 \\
\hline
\end{tabular}

Untuk menjabaran secara rinci PAM maka akan dibahas berdasarkan dua garis besari yaitu analisis daya saing dan analisis dampak kebijakan pemerintah. Analisis daya saing memiliki indikator yaitu berdasarkan keunggulan kompetitif dan komparatif. Analisis dampak kebijakan memiliki indikator yaitu dampak kebijakan input, kebijakan output dan kebijakan input-output.

\section{Analisis Daya Saing}

\section{Analisis Keunggulan Kompetitif}

Keunggulan kompetitif merupakan suatu keadaan usaha tani apakah dapat bersaing dengan produsen - produsen dalam negeri dengan biaya - biaya privat yang dikeluarkan dan output yang diterima. Untuk mengukur keunggulan kompetitif dapat terlihat dari keuntungan privat dan rasio biaya privatnya (PCR). Keuntungan privat dan dan rasio biaya privat (PCR) usaha tani padi tersaji dalam tabel

5.

Tabel 5. Keuntungan Privat dan Rasio Biaya Privat (PCR)

\begin{tabular}{ll}
\hline Keuntungan Privat (Rp/ha) & PCR \\
\hline 15.295 .170 & 0,428 \\
\hline
\end{tabular}

Sumber: Tabel PAM diolah

Keuntungan privat usaha tani sebesar Rp 15.295.170 /Ha. Keuntungan usaha tani dapat lebih tinggi apabila penggunaan input produksi lebih efisien. Beberapa komponen yang mengakibatkan besarnya biaya yaitupenggunaan pupuk .
Penggunaan pupuk Urea oleh responden diatas rekomendasi pemupukan sebesar 200 sampai $290 \mathrm{~kg} / \mathrm{ha}$ yaitu $418,58 \mathrm{~kg} / \mathrm{ha}$. Keadaan tersebut diikuti juga dengan penetapan harga eceran tertinggi pupuk bersubsidi yang belum merata sehingga 
JURNAL ILMIAH AGRINECA

ISSN : 2721-074X (Online) - 2301-6698 (Print)

Available on : http://ejournal.utp.ac.id/index.php/AFP/index

This is Under CC BY SA Licence

petani masih menerima harga diatas HET. Apabila dikaitkan dengan luas kepemilikan lahan rata-rata responden $5.482 \mathrm{~m}^{2}$ maka keuntungan responden bisa lebih tinggi apabila penggunaan input sesuai rekomendasi dan subsidi yang diberikan lebih merata.

Keunggulan kompetitif dapat dilihat dari nilai PCR. Jika nilai PCR usaha tani padi organik dan $<1$ maka sistem komoditas memiliki keunggulan kompetitif. Semakin kecil nilai PCR maka semakin sedikit biaya domestik berdasarkan harga aktual untuk menghasilkan output yang dikeluarkan. Berdasarkan tabel 5, nilai PCR sebesar 0,428. Hal ini berarti bahwa untuk mendapatkan nilai tambahan output sebesar satu satuan diperlukan tambahan biaya faktor domestik sebesar 0,428 . Nilai dari PCR usaha tani menunjukkan nilai kurang dari satu sehingga dapat dikatakan bahwa usaha tani memiliki keunggulan kompetitif.

\section{Analisis Keunggulan Komparatif}

Keunggulan komparatif merupakan ukuran daya saing suatu usaha dalam keadaan pasar persaingan sempurna. Dalam pasar persaingan sempurna faktor kebijakan pemerintah khususnya dalam pemberian subsidi dihilangkan. Dengan dihilangkannya faktor subsidi maka keuntungan yang didapat yaitu berdasarkan keuntungan sosial. Keuntungan berdasarkan harga sosial dapat dijadikan indikator adanya keunggulan komparatif. Selain dari keuntungan sosial, keunggulan komparatif juga dapat diketahui dari nilai rasio biaya sumberdaya domestik. Data keuntungan sosial dan rasio biaya sumberdaya domestik (DRCR) usaha tani padi organik dan tersaji dalam tabel 6 .

Tabel 6. Keuntungan Sosial dan Rasio Biaya Sumberdaya Domestik (DRCR)

\begin{tabular}{ll}
\hline Keuntungan Sosial (Rp/ha) & DRCR \\
\hline 795.039 & 0,935
\end{tabular}

Sumber: Tabel PAM diolah

Berdasarkan data diatas usaha tani menguntungkan pada tingkat harga sosial. Keuntungan sosial usaha tani sebesar $\mathrm{Rp}$ 795.039/Ha. Nilai keuntungan sosial yang menunjukkan angka lebih dari nol berarti tanpa adanya kebijakan pemerintah usaha tani padi akan menguntungkan. Walaupun usaha tani menguntungkan namun nilai keuntungan sosial usaha tani padi sangat kecil tu berarti apabila tidak ada kebijakan pemerintah maka petani hanya akan mendapatkan keuntungan sebesar Rp 795.039/ha. Apabila dibandingkan nilai keuntungan berdasarkan harga privat dan sosial, usaha tani memiliki keuntungan lebih besar secara sosial .Itu berarti kebijakan pemerintah baik secara mikro dan makro belum dapat memberikan keuntungan lebih tinggi dari keuntungan yang seharusnya diterima petani.

Selain dilihat dari keuntungan sosial, keunggulan komparatif juga dapat dilihat dari nilai DRCR.Jika nilai DRCR kurang dari 1 menunjukkan usaha tani memiliki keunggulan komparatif karena mampu membiayai faktor domestik dengan harga sosial yang berlaku. Berdasarkan tabel 6, nilai DRCR yaitu 0,935. Nilai sebesar 0,935 diartikan bahwa untuk memproduksi atau menambah nilai tambah output sebesar satu satuan dibutuhkan tambahan sumberdaya domestik sebesar 0,935 . Dengan nilai tersebut dapat dikatakan bahwa usaha tani memiliki keunggulan komparatif. Meskipun demikian, nilai DRCR sudah mendekati satu sehingga usaha tani dikhawatirkan sudah tidak lagi memiliki keunggulan komparatif apabila kebijakan pemerintah tidak mampu untuk membuat usaha tani padi lebih efisien lagi.Ketidakefisienan suatu usaha tani juga membuat komoditas tersebut tidak mampu bersaing pada perdagangan internasional. 
JURNAL ILMIAH AGRINECA

ISSN : 2721-074X (Online) - 2301-6698 (Print)

Available on : http://ejournal.utp.ac.id/index.php/AFP/index

This is Under CC BY SA Licence

Analisis Dampak Kebijakan

\section{Dampak Kebijakan Input}

Dampak kebijakan input dapat diketahui dari nilai transfer input (TI), transfer faktor (TF), dan koefisien proteksi input nominal (NPCI). Data nilai transfer input (TI), transfer faktor (TF), dan koefisien proteksi input nominal (NPCI) tersaji dalam tabel 7.

Tabel 7.Nilai Transfer Input (TI), Transfer Faktor (TF), dan Koefisien Proteksi

\begin{tabular}{lll}
\hline Transfer Input (Rp/ha) & Tranfer Faktor $(\mathrm{Rp} / \mathrm{ha})$ & NPCI \\
\hline$(1.258 .627)$ & 0 & 0,724 \\
\hline
\end{tabular}

Transfer input merupakan divergensi input tradable privat dan input tradable sosial. Nilai TI > 0 menunjukkan adanya transfer dari petani ke produsen input tradable.Berdasarkan data tabel 7 , diketahui nilai transfer input bernilai negatif sebesar Rp 1.258.627. Nilai negatif berarti terdapat subsidi dari pemerintah terhadap input tradable sehingga harga yang diterima petani lebih kecil daripada harga sosialnya. Dalam penelitian ini memang terdapat subsidi yang diberikan pemerintah yaitu dalam bentuk subsidi pupuk, benih dan pestisida.

Transfer faktor merupakan divergensi input non tradable privat dan input non tradable sosial. Nilai $\mathrm{TF}>0$ menunjukkan adanya transfer dari petani ke produsen input non tradable. Berdasarkan data diatas diketahui nilai transfer faktor usaha tani 0 . Nilai 0 disebabkan oleh penggunaan input non tradable khususnya tenaga kerja pertanian di Indonesia rata - rata bukan tenaga ahli sehingga tidak memiliki harga internasional.

NPCI adalah rasio antara biaya tradable input privat terhadap biaya tradable input sosial. Nilai NPCI $>1$ menunjukkan adanya proteksi terhadap produsen input tradable. Artinya harga privat input tradable lebih tinggi dibandingkan harga dunia sehingga dalam hal ini petani yang menanggung dengan harga input yang tinggi. Sebaliknya apabila NPCI < 1 menunjukkan bahwa petani menerima subsidi input tradable dari pemerintah. Nilai NPCI usaha tani sebesar 0,724 . Angka tersebut menunjukkan bahwa terdapat subsidi untuk petani dalam rangka memenuhi kebutuhan input tradablenya.

2. Dampak Kebijakan Output

Dampak kebijakan output dapat diketahui dari nilai transfer output (TO) dan koefisien proteksi output nominal (NPCO). Nilai transfer output (TO) dan koefisien proteksi input nominal (NPCO) disajikan dalam tabel 8.

Tabel 8. Nilai transfer output (TO) dan koefisien proteksi input nominal (NPCO)

\begin{tabular}{ll}
\hline Transfer Output & NPCO \\
\hline 13.241 .505 & 1,789 \\
\hline
\end{tabular}

Berdasarkan data tabel 8 , transfer output positif sebesar Rp 13.241.505. Hal tersebut menunjukkan bahwa harga internasional beras lebih rendah dibandingkan harga yang diterima petani sehingga petani mendapatkan keuntungan lebih tinggi. Selain dari transfer output dampak kebijakan pemerintah juga dapat diketahui dari nilai NPCO. Nilai NPCO berdasarkan data diatas yaitu 1,789 . Nilai NPCO lebih dari satu menunjukkan bahwa pemerintah berhasil untuk meningkatkan harga jual output dalam negerilewat kebijakan - kebijakan yang ada sehingga menjadi lebih tinggi dari harga sosialnya.

\section{Dampak Kebijakan Input-Output}

Dampak kebijakan pemerintah dari input output dapat diketahui dengan nilai net transfer, EPC, PC dan SRP. Nilai net transfer, EPC, PC dan SRP tersaji dalam tabel 9. 
JURNAL ILMIAH AGRINECA

ISSN : 2721-074X (Online) - 2301-6698 (Print)

Available on : http://ejournal.utp.ac.id/index.php/AFP/index

This is Under CC BY SA Licence

Tabel 9. Nilai Net Transfer, EPC, PC dan SRP

\begin{tabular}{lc}
\hline NT & EPC \\
\hline 14.500 .132 & 2,186 \\
\hline $\begin{array}{l}\text { Nilai Net Transfer merupakan nilai yang } \\
\text { menunjukkan dampak }\end{array}$ & kebijakan
\end{tabular}
pemerintah secara keseluruhan baik untuk input maupun output. Nilai Net transfer > 0 menunjukkan tambahan surplus produsen yang disebabkan oleh kebijakan pemerintah terhadap input dan output seperti terjadi pada usaha tani padi yang suplus Rp 14.500.132/ha.

Nilai Koefisien Protektif Efektif (EPC) adalah rasio nilai tambah pada tingkat harga privat dengan harga sosialnya.Nilai EPC usaha tani sebesar 2,186 . Nilai lebih dari satu berarti petani mendapatkan proteksi dari pemerintah dengan kebijakan input outputnya.

Koefisien Keuntungan (PC) digunakan untuk mengukur dampak dari keseluruhan transfer atas keuntungan privat, yang merupakan rasio antara keuntungan privat terhadap keuntungan sosial.Nilai PC yang diperoleh pada usaha tani sebesar 19,238.Nilai positif menunjukkan bahwa petani tidak mengalami kerugian namun keuntungan yang diterima petani lebih rendah dari seharusnya.

Nilai Rasio Subsidi bagi Produsen (SRP ) merupakan indikator yang menunjukkan tingkat penambahan dan pengurangan penerimaan atas pengusahaan suatu komoditas karena adanya kebijakan pemerintah. Nilai SRP pada usaha tani bernilai positif 0,864 . Dengan nilapositif tersebut diartikan bahwa kebijakan pemerintah terhadap input dan output menguntungkan petani karena petani membayar lebih rendah dari biaya opputunity cost untuk memproduksi sebesar 86,4 persen usaha taninya.

\section{KESIMPULAN DAN SARAN}

Usaha tani padi di Kecamatan Susukan Kabupaten Semarang ini mePguntungkan secara pSiRet dan sosial. Kengnabgan privat usaha0t8gi4 sebesar Rp 15.295.170/Ha dan keuntungan sosial sebesar Rp 795.039/Ha. Kecilnya keuntungan sosial usaha tani padi disebabkan oleh rendahnya harga dunia untuk beras dan tingginya biaya input tradable.

Usaha tani memiliki keunggulan kompetitif dan komparatif. Keunggulan kompetitif terlihat dari nilai PCR < 1 yaitu sebesar 0,428 dan keunggulan komparatif dari nilai DRCR $<1$ sebesar 0,935. Nilai DRCR padi mendekati satu yang berarti usaha tani dikhawatirkan sudah tidak memiliki keunggulan komparatif apabila tidak ada peran pemerintah didalamnya.

Kebijakan Pemerintah dibedakan menjadi 3: Kebijakan input, Terdapat subsidi input yang diterima petani terlihat dari nilai transfer input negatif dan nilai NPCI < 1. Nilai Transfer faktor bernilai Rp 0 karena tidak ada harga internasional untuk input non tradable. Kebijakan Output. Kebijakan output terlihat dari transfer output (TO) dan nilai NPCO. TO usaha tani padi yaitu Rp 13.241.505 dan NPCO sebesar 1,789. Dengan demikian terdapat kebijakan untuk memproteksi output sehingga harga jual privat lebih tinggi dari harga jual sosial. Kebijakan Input Output, Usaha tani memilikiTransfer Bersih sebesar Rp 14.500.132, EPC sebesar 2,186, PC sebesar 19,238 dan SRP sebesar 0,864. Secara keseluruhan kebijakan input output berdampak pada usaha tani yang mendapatkan keuntungan dan proteksi dari kebijakan pemerintah untuk input output.

Adapun saran yang dapat diberikan yaitu pemerintah sebaiknya kebijakan subsidi pupuk dan pestisida tetap dilanjutkan supaya usaha tani tetap berdaya saing khususnya secara kompetitif. Bagi petani sebaiknya 
JURNAL ILMIAH AGRINECA

ISSN : 2721-074X (Online) - 2301-6698 (Print)

Available on : http://ejournal.utp.ac.id/index.php/AFP/index

This is Under CC BY SA Licence

mengurangi penggunaan pupuk sehingga sesuai dengan rekomendasi Dinas Pertanian atau para peneliti. Bagi pemasar produk padi sebaiknya menyasar pasar dalam negeri karena harga internasional padi lebih rendah.

\section{DAFTAR PUSTAKA}

Anapu, H., E.Ruaw, C.Talumingan, A.Lobo dan L.Pangemanan. 2005. Dampak Kebijakan Tarif Impor Beras di Kabupaten Minahasa, Sulawesi Utara. Dalam Buku Aplikasi Policy Analysis Matrix pada Pertanian di Indonesia. Yayasan Obor Indonesia, Jakarta.

Ali, M., Purwanti, S., \& Hidayati, S. (2019). Intercropping System for Growth and Yield in Local Varieties of Madura. Agricultural Science, 3(1), 22-30.

Badan Pusat Statistik, 2017. Perkembangan Ekspor dan Impor Indonesia November 2017. [Online] https://www.bps.go.id/[Diakses 2018].

Darmawan, D., 2014. Metode Penelitian Kuantitatif. Bandung: PT.Remaja Rosdakarya.

Dewi, H. E., Koestiono, D. \& Suhartini, 2013. Keunggulan Komparatif dan Dampak Kebijakan Pengurangan Subsidi Input Terhadap Pengembangan Komoditas Kentang di Kota Batu. Habitat, XXIV(2), pp. 86-95.

Gerungan, L. M., 2013. Analisis Keunggulan Komparatif dan Kompetitif Komoditi Biji Pala di Minahasa Utara. Cocos, 2(2), pp. 1-15.

Jakiyah, U., Baga, L. M. \& Tinnaprilla, N., 2016. Dampak Kebijakan Pemerintah Terhadap Usaha Tani Beras Organik di Provinsi Jawa Barat. Buletin Ilmiah Litbang Perdaganga, 10(1), pp. 129-146.
Monke, E. \& Pearson, E., 1989. The Policy Analysys Matrix for Agricultural Developement. London: Cornell University Press.

Pearson, S., Gotsch, C. \& Bahri, S., 2005. Aplikasi Policy Analysis Matrix Pada Pertanian Indonesia. Jakarta: Yayasan Obor Indonesia.

Sayekti, A. L. \& Zamzami, L., 2011. Analisis Keunggulan Komparatif dan Kompetitif Jeruk Siam di Sentra Produksi. Widyariset, 14(1), pp. 19.

Setiawan, K., Hartono, S. \& Suryantini, A., 2014. Analisis Daya Saing Komoditas Kelapa di Kabupaten Kupang. Agritech, 34(1), pp. 88-93.

Sugiyono, 2010. Metode Penelitian Pendidikan Pendekatan Kuantitatif, Kualitatif dan $R \& D$. Bandung: Alfabeta.

Surowinoto, S., 1982. Budidaya Tanaman Padi. Bogor: Jurusan Agronomi Faperta IPB.

Tarigan, R., 2005. Perencanaan Pembangunan Wilayah. Jakarta: Bumi Aksara 